\title{
Percutaneous left atrial appendage occlusion - treatment outcomes and 6 months of follow-up - a single-center experience
}

\author{
Michał Karczewski ${ }^{1}$, Sebastian Woźniak ${ }^{1}$, Radomir Skowronek ${ }^{1}$, Marian Burysz ${ }^{1}$, Marcin Fischer ${ }^{1}$, \\ Lech Anisimowicz ${ }^{2}$, Marcin Demkow ${ }^{3}$, Marek Konka ${ }^{4}$, Wojciech Ogorzeja ${ }^{1}$ \\ ${ }^{1}$ Department of Cardiac Surgery, Regional Specialist Hospital, Grudziądz, Poland \\ ${ }^{2}$ Clinic of Cardiac Surgery, Antoni Jurasz University Hospital No. 1, Bydgoszcz, Poland \\ ${ }^{3}$ Clinic of Coronary and Structural Heart Diseases, Institute of Cardiology, Warsaw, Poland \\ ${ }^{4}$ Clinic of Congenital Cardiac Defects, Institute of Cardiology, Warsaw, Poland \\ Kardiochirurgia i Torakochirurgia Polska 2016; 13 (2): 98-104
}

\begin{abstract}
Aim: To present the results of treatment and evaluate 6 months of follow-up in a group of patients with non-valvular atrial fibrillation, who underwent the procedure of percutaneous left atrial appendage occlusion (PLAAO).

Material and methods: Percutaneous left atrial appendage occlusion was performed in 34 patients with non-valvular atrial fibrillation and contraindications for oral anticoagulation therapy. The risk of thromboembolic and bleeding complications was determined based on the $\mathrm{CHA}_{2} \mathrm{DS}_{2} \mathrm{VASC}$ and HAS-BLED scales. The Amplatzer Amulet system from St. Jude Medical was used. On the first postoperative day, all patients were started on double antiplatelet therapy with $75 \mathrm{mg} /$ day of acetylsalicylic acid (ASA) and $75 \mathrm{mg} /$ day of clopidogrel (CLO). On the $30^{\text {th }}$ postoperative day, the efficacy of the antiplatelet therapy was assessed with impedance aggregometry using a Multiplate analyzer (Roche). Echocardiographic examinations were performed intraoperatively and on the first postoperative day; subsequently, follow-up examinations were conducted 1 and 6 months after the implantation.
\end{abstract}

Results: In all patients, proper occluder position was observed throughout the follow-up. No leakage or thrombi around the implants were found. No strokes or bleeding complications associated with the antiplatelet therapy were observed. Multiplate assessment of platelet activity was conducted in 20 out of 34 patients. The efficacy of ASA treatment was demonstrated in all patients; no response to clopidogrel treatment was observed in 5 out of 20 patients. One patient suffered from cardiac tamponade, which required the performance of full sternotomy. Local complications (hematomas of the inguinal region) were observed in 3 patients. One of the patients died for reasons unrelated to the procedure.

Conclusions: Percutaneous left atrial appendage occlusion is an effective procedure in patients with non-valvular atrial fibrillation and contraindications for chronic anticoagulation

\section{Streszczenie}

Cel: Przedstawienie wyników leczenia oraz ocena sześciomiesięcznego okresu obserwacji w grupie chorych z niezastawkowym migotaniem przedsionków poddanych procedurze przezskórnego zamknięcia uszka lewego przedsionka.

Materiał i metody: Zabieg przezskórnego zamknięcia uszka lewego przedsionka (percutaneous left atrial appendage occlusion - PLAAO) wykonano u 34 pacjentów z niezastawkowym migotaniem przedsionków i przeciwwskazaniami do doustnej terapii przeciwkrzepliwej. Ryzyko wystapienia powikłań zatorowo-zakrzepowych i krwotocznych określano na podstawie skal $\mathrm{CHA}_{2} \mathrm{DS}_{2}$ VASC oraz HAS-BLED. Stosowano system St. Jude Medical Amplatzer Amulet. U wszystkich pacjentów włączono w pierwszym dniu pooperacyjnym podwójną terapię przeciwpłytkową kwasem acetylosalicylowym (ASA) w dawce 75 mg/ dobę oraz klopidogrelem (KLO) w dawce 75 mg/dobę. Skuteczność leczenia przeciwpłytkowego oceniono w 30. dobie pozabiegowej metodą agregometrii impedancyjnej aparatem Multiplate Roche. Badania echokardiograficzne wykonywano $w$ trakcie procedury, w pierwszej dobie pooperacyjnej oraz badania kontrolne po 1 i 6 miesiącach od implantacji.

Wyniki: U wszystkich chorych stwierdzono prawidłowe położenie okludera w całym okresie obserwacji. Nie stwierdzono przecieków i skrzeplin wokół implantu. Nie obserwowano udarów i powikłań krwotocznych związanych z leczeniem przeciwpłytkowym. Badanie aktywności płytek Multiplate przeprowadzono u 20 spośród 34 chorych. W badaniu wykazano skuteczność leczenia ASA u wszystkich chorych oraz brak odpowiedzi na leczenie KLO u 5 spośród 20 chorych. Wystąpiła 1 tamponada serca wymagająca wykonania pełnej sternotomii. U 3 chorych obserwowano powikłania miejscowe - krwiaki okolicy pachwinowej. Nastąpił 1 zgon pacjentki z przyczyn niezwiązanych z zabiegiem.

Wnioski: Zabieg przezskórnego zamknięcia uszka lewego przedsionka u chorych z niezastawkowym migotaniem przed-

Address for correspondence: Dr Sebastian Woźniak, Department of Cardiac Surgery, Regional Specialist Hospital, 15/17 Rydygiera St, 86-300 Grudziądz, Poland, e-mail: woz-seb@o2.pl 
therapy. Further observation is necessary to evaluate the longterm results.

Key words: percutaneous left atrial appendage occlusion, nonvalvular atrial fibrillation.

\section{Introduction}

Atrial fibrillation (AF) is the most commonly diagnosed supraventricular cardiac arrhythmia. Its incidence rises with age: from $0.5 \%$ in individuals younger than 40 to over $15 \%$ in individuals above the age of 80 [1]. The most serious risks associated with AF are thromboembolic complications, ischemic stroke in particular. It is estimated that approximately $90 \%$ of all thrombi from the left atrium originate from its appendage [1]. Strokes are considered to be the third major cause of death in Poland and Europe and the most common cause of disability in individuals $>40$ years of age. The yearly incidence of stroke as a complication of AF is estimated at approximately $5 \%$ [2, 3]. Atrial fibrillation is observed in $17 \%$ of patients diagnosed with stroke; above the age of 80 , this rises to $25 \%$ [1]. The frequency of these incidents is constantly rising despite the increasingly widespread use of anticoagulation therapy. In practice, treatment with oral anticoagulants (coumarin derivatives and novel oral anticoagulants) proves dangerous for many patients. In the case of coumarin derivatives, difficulties in maintaining INR values within the therapeutic range may lead to the occurrence of severe complications. These include both thromboembolic complications (such as ischemic stroke) and bleeding complications (such as hemorrhagic stroke or bleeding into the gastrointestinal tract). According to the literature, $23 \%$ of significant life-threatening bleeding events occurred after the INR value exceed-ed 4 [4]. The novel oral anticoagulants introduced over the last few years are becoming increasingly widespread in the treatment of AF patients despite their relatively high prices. In comparison with coumarin derivatives, they are associated with lower risk of hemorrhagic stroke and do not require INR monitoring.

The above circumstances have prompted a search for an effective method of AF prevention that does not have the flaws associated with the use of oral anticoagulants.

According to multicenter randomized clinical studies, percutaneous left atrial appendage occlusion (PLAAO) has proved to be a safe procedure, and its results are not inferior to treatment with warfarin or novel oral anticoagulants in terms of effectiveness in preventing ischemic stroke and thrombotic complications [1-4].

\section{Aim}

The aim of this paper is to present the results of PLAAO treatment in a group of 34 patients with non-valvular atrial fibrillation and contraindications for the use of oral anticoagulants.

\section{Material and methods}

Percutaneous left atrial appendage occlusion was performed in 34 patients: 20 men and 14 women. The mean sionków i przeciwwskazaniami do przewlekłej terapii przeciwkrzepliwej jest procedurą skuteczną. Konieczna jest dalsza obserwacja chorych w celu oceny wyników odległych.

Słowa kluczowe: przezskórne zamknięcie uszka lewego przedsionka, niezastawkowe migotanie przedsionków.

age was 72 years (46-89 years). Paroxysmal atrial fibrillation was found in the medical history of $38 \%$ of the patients, while $58 \%$ had longstanding persistent atrial fibrillation. Half of the qualified patients suffered from serious bleeding requiring hospitalization at the department of gastroenterology. The qualification criteria were in accordance with the guidelines of the European Society of Cardiology from 2012. The procedure was performed in patients with non-valvular AF. In most of the patients, prior oral antithrombotic treatment had been associated with the occurrence of complications or had been unsuccessful. Patient characteristics, including indications for PLAAO, are presented in Table I. The study included patients with contraindications for oral anticoagulants and patients in whom the adequate dosage could not be determined due to labile INR values. Risk factors for stroke were assessed using the $\mathrm{CHADS}_{2}$ and $\mathrm{CHA}_{2} \mathrm{DS}_{2}$ VASc scales and the risk of bleeding assessment based on the HAS-BLED score. The mean $\mathrm{CHADS}_{2}$ score was 3 points, $\mathrm{CHA}_{2} \mathrm{DS}_{2}$ VASc: 5 points, and HAS-BLED: 4.8 points.

According to the ESC guidelines, the performance of PLAAO should be considered in patients with high risk of stroke and contraindications for oral antithrombotic

Tab. I. Preoperative characteristics of the group of 34 patients qualified for PLAAO procedures. Mean values and min-max ranges are presented. The occurrence of stroke and bleeding complications is presented as percentages

\begin{tabular}{ll} 
Parameter & Value \\
\hline Men & 20 \\
\hline Women & 14 \\
\hline Weight $[\mathrm{kg}]$ & $72(46-87)$ \\
\hline Height $[\mathrm{m}]$ & $77.2(36-128)$ \\
\hline BMI $\left[\mathrm{kg} / \mathrm{m}^{2}\right]$ & $1.65(1.47-1.95)$ \\
\hline Paroxysmal AF & $28.42(15.79-47.59)$ \\
\hline Longstanding persistent AF & $13(38 \%)$ \\
\hline Ischemic stroke & $20(58 \%)$ \\
\hline Hemorrhagic stroke & $10(29 \%)$ \\
\hline Bleeding in medical history & $1(2.9 \%)$ \\
\hline Previous cardiac surgery & $17(50 \%)$ \\
\hline HAS-BLED score & $14(42 \%)$ \\
\hline CHA $_{2}$ DS 2 VASc score & $4.8(3-7)$ \\
\hline CHADS $_{2}$ score & $5.4(3-9)$ \\
\hline EF $[\%]$ & $3.2(3-6)$ \\
\hline Occluder diameter [mm] & $53(29-68)$ \\
\hline
\end{tabular}


therapy: recommendation class $\mathrm{ll}$, evidence level $B$ [1]. A $\mathrm{CHA}_{2} \mathrm{DS}_{2}$ VASc score of 3 points is used as a qualifying criterion in the recommendations of the Polish National Health Fund (Narodowy Fundusz Zdrowia - NFZ). The procedure is contraindicated in patients diagnosed with mitral valve stenosis or the presence of thrombus in the left atrial appendage.

\section{Implantation procedure}

All patients underwent transesophageal echocardiography (TEE) 24 hours before the procedure in order to exclude the presence of thrombus in the left atrial appendage. The patients were hydrated in order to optimize atrial filling. The procedure was performed under general anesthesia and antibiotic protection ( $2^{\text {nd }}$ generation cephalosporin). Heparin, dosed at $100 \mathrm{U} / \mathrm{kg}$ b.w., was administered in two doses: the first after the introduction of the catheter into the lumen of the superior vena cava, the second after transseptal puncture and the introduction of the catheter into the lumen of the left atrium. Mean left atrial pressure was measured, and $10 \mathrm{~mm} \mathrm{Hg}$ was assumed as the value allowing for continuation of the procedure. Using contrast fluoroscopy, the left atrial appendage was visualized selectively in order to evaluate the anatomy. Angiography was performed using RAO $20^{\circ}$ - caudal $20^{\circ}$ and RAO $30^{\circ}$ - cranial $10^{\circ}$ projections. Simultaneously, the performed actions were constantly monitored using 2D and 3D TEE. During the first stage of the procedure, this examination is particularly useful for determining the optimal site of transseptal puncture; during the subsequent stages, TEE is used to establish the dimensions of the left atrial appendage, control the implantation process, and provide ultimate confirmation that the occluder system is in the proper position. For the first time in Poland, our center performed LAAO procedures using the EchoNavigator, a system for precise tissue visualization. It provides a perfect view of the anatomy, facilitating more accurate diagnosis and the selection of adequate treatment methods. EchoNavigator automatically combines the imaging functions of TEE and angiography in real time. This significantly improves the effectiveness of the performed procedure, simultaneously reducing the amount of contrast and the dose of radiation to which the patient is exposed. To close the appendage of the left atrium, we used the Amplatzer Amulet occluder manufactured by St. Jude Medical.

This type of occluder consists of two main elements:

1. A cylindrical core, which is introduced into the lumen of the left atrial appendage; the core is equipped with numerous "hooks" along its margin, anchoring it to the walls of the appendage. This part of the occluder is called its "lobe" by the manufacturer.

2. A flat, platelike disk covering the appendage's ostium from the side of the atrial cavity.

The occluder's diameter was selected based on echocardiographic examination and tables provided by the manufacturer (St. Jude). When the appendage's dimension fell in between the table values, the larger occluder was implanted. The removal of the delivery systems and placing a compression dressing on the femoral vein constituted the last stage of the procedure.

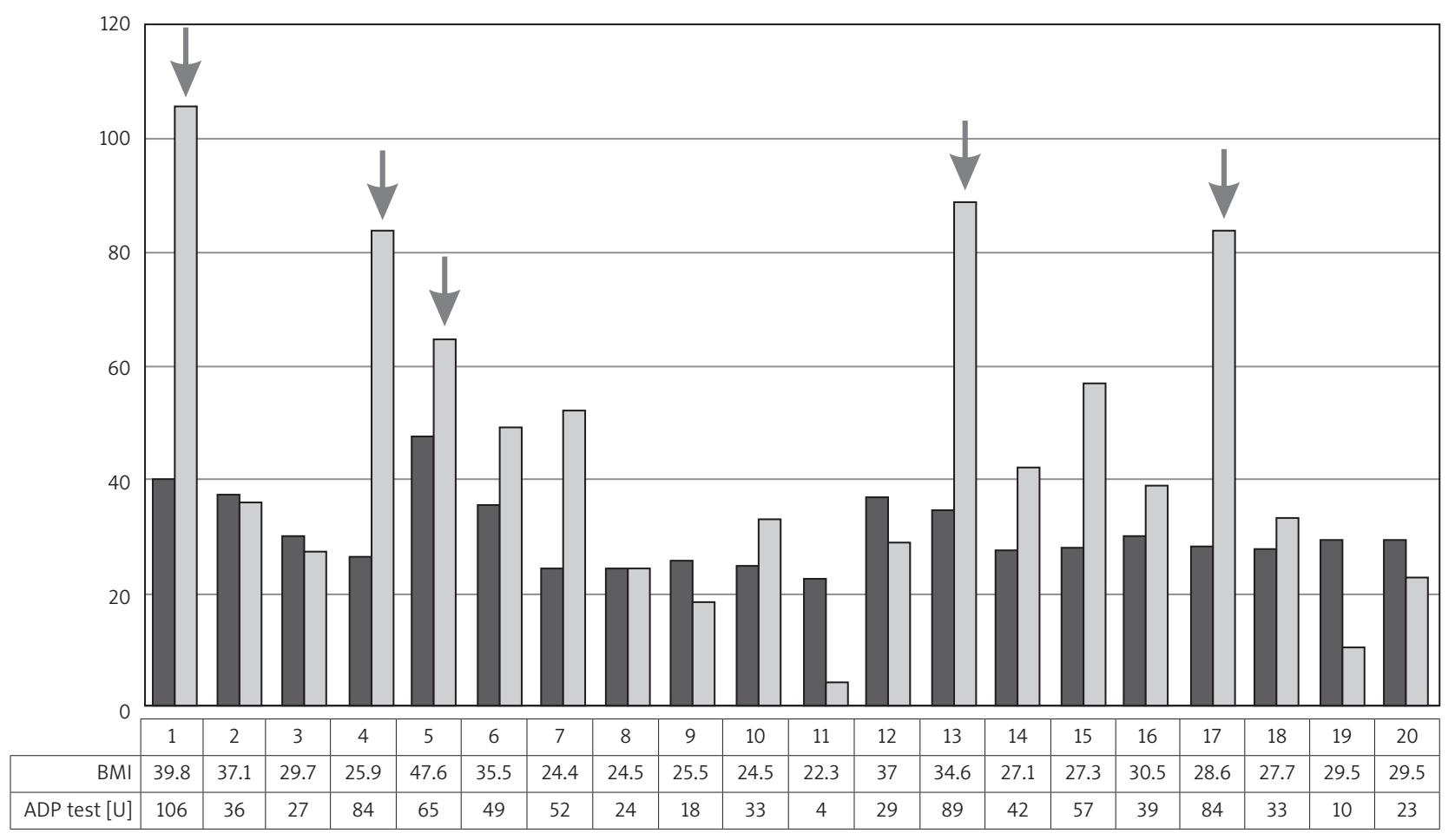

$\square$ BMI $\square$ ADP test [U]

Fig. 1. Body mass index values and ADP test results in a group of 20 patients. The yellow arrows indicate patients in whom the ADP test values correspond to the reference values for no clopidogrel use 


\section{The criteria for the correct implantation}

The criteria for the correct implantation of the occlusion system include:

1) The expanded lobe is tire-shaped,

2) The lobe is separated from the disk, ensuring a stable position,

3) The disk is concave,

4) The lobe axis is aligned with the axis of the left atrial appendage neck,

5) $2 / 3$ of the lobe's length is placed distally in relation to the circumflex branch of the left coronary artery (Figs. 1-3).

\section{Postoperative management}

After the procedure, each patient was transferred to the postoperative room, where they were woken and extubated within 1 hour after the implantation. During the first postoperative day, transathoracic echocardiography (TEE) was performed in order to assess the occluder's position and the presence of fluid in the pericardial sac. In cases of doubt, additional TEE was performed. During postoperative hospitalization, $1 \mathrm{mg} / \mathrm{kg}$ b.w. of low-molecular-weight heparin was administered twice per day, and double antiplatelet therapy was started: ASA $75 \mathrm{mg}$ and CLO $75 \mathrm{mg}$. This antiplatelet therapy was recommended for a period of 6 months. Subsequently, an ASA dose of $75 \mathrm{mg} /$ day was recommended. The efficacy of the antiplatelet treatment was assessed on the $30^{\text {th }}$ postoperative day. Due to the limited availability of the Multiplate analyzer (Roche Diagnostics), blood platelet activity was tested in 20 out of 34 patients using multiple electrode impedance aggregometry. The method consists in measuring the change in electrical impedance while blood platelets adhere and aggregate to two electrodes, as registered by the analyzer for 6 consecutive minutes. The result takes the form of an receiver operating characteristic (ROC) curve. The obtained parameters are aggregation and velocity (of the curve increase). The result is expressed as the area under the curve (AUC). The reference range of the ASPI test without the use of ASA is 51-117 $\mathrm{U}$. The reference range of the ADP test without the use of clopidogrel is 57-113 U. Due to the assumed regimen of double antiplatelet therapy, each patient underwent an ASPI test to determine the efficacy of ASA and an ADP test to establish the sensitivity to clopidogrel. All patients reported regular self-administration of the recommended medication doses $(75 \mathrm{mg}$ ASA and $75 \mathrm{mg}$ CLO). In the described patient group, no resistance to ASA was observed; the mean value of the ASPI test was $23 \mathrm{U}$. The mean value of the ADP test was $45 \mathrm{U}$. The ADP values in $5(25 \%)$ patients with high body mass index (BMI) fell within the reference range for no clopidogrel use. The $B M I$ values and ADP results are collated in Figure 1.

\section{Statistical analysis}

Statistical analysis was performed using Pearson's $r$ : the result (0.332) demonstrated a weak correlation between the BMI values and ADP test results. A detailed collation of BMI and ADP values in the 5 described patients

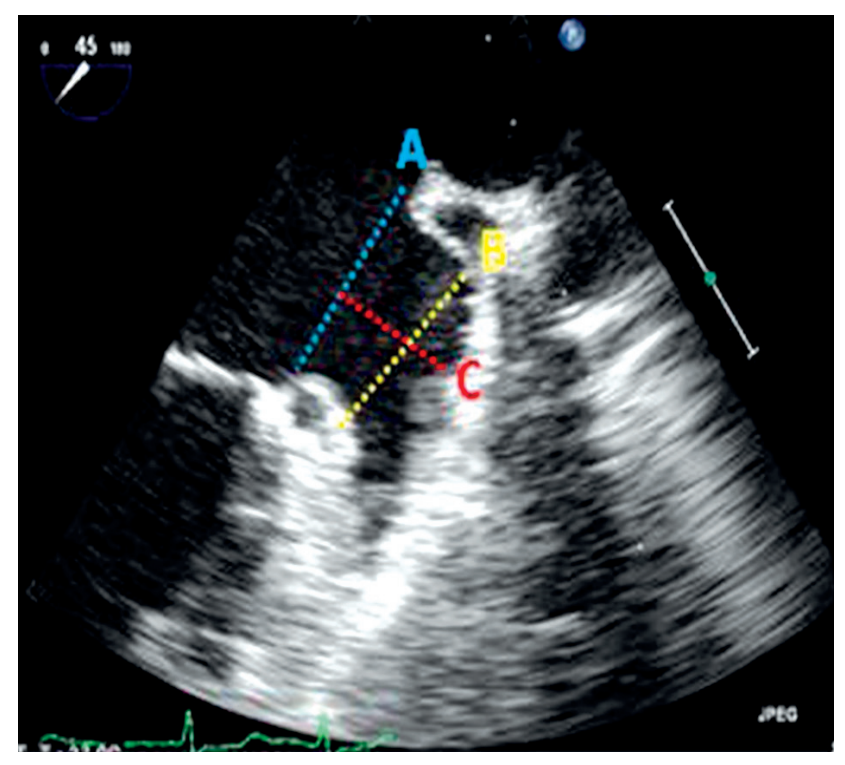

Fig. 2. Establishing the dimensions of the LA appendage
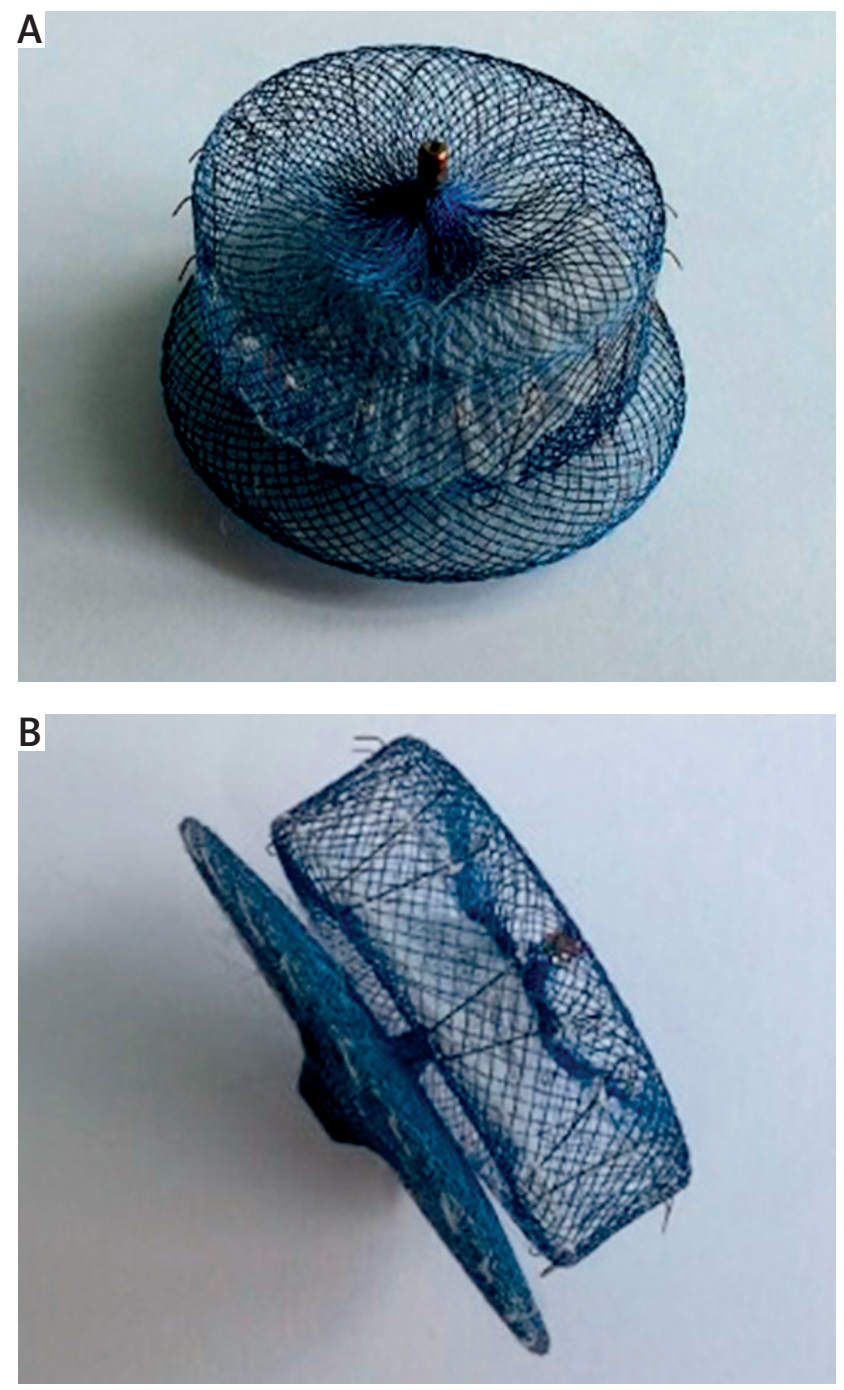

Fig. 3 A, B. Amplatzer Amulet - a left atrial appendage occluder from St. Jude Medical 
Tab. II. Characteristics of 5 patients in whom the ADP test values correspond to the reference values for no clopidogrel use

\begin{tabular}{lcccc} 
Gender & Age & BMI & ASP test (U) & ADP test (U) \\
Male & 64 & 39.79 & 34 & 106 \\
\hline Male & 77 & 28.63 & 38 & 84 \\
\hline Female & 65 & 25.91 & 38 & 84 \\
\hline Female & 72 & 47.59 & 37 & 65 \\
\hline Male & 74 & 34.63 & 35 & 89 \\
\hline
\end{tabular}

is presented in Table II. Control TEE was performed 1 and 6 months after the implantation.

\section{Results}

No occluder dislocation, leakage, or thrombi within the left atrium were observed during the hospitalization. There were no cases of ischemic/hemorrhagic stroke, mitral insufficiency, or myocardial infarction. The most common complications after the implantation were local complications observed in 3 patients - hematomas of the subcutaneous tissue in the inguinal region, which occurred after femoral vein puncture. In 1 patient, cardiac tamponade developed, which required surgical decompression in the operating room. The bleeding was found to have originated from an injury of the left pulmonary artery's adventitia by the occluder hooks. This complication, associated with the particular topography of the appendage and pulmonary artery, is very rare. This type of anatomy has recently been included in relative contraindications for PLAAO by an expert panel. Throughout the 6 months of follow-up, there were no bleeding complications, arterial embolisms, or strokes. The TEE did not demonstrate any cases of occluder dislocation, leakage around the occluder, or thrombi on the disks.

A detailed discussion of adverse events is presented in Table III. PLAAO.

Table IV presents the length of hospitalization after

Tab. III. Adverse events in the group of 34 patients undergoing PLAAO

\begin{tabular}{|c|c|c|c|c|}
\hline No. & Complication & Cause of complication & Management & Conclusions \\
\hline 1 & Cardiac tamponade & $\begin{array}{l}\text { Due to the unfavorable anatomy of } \\
\text { the appendage, the hooks stabili- } \\
\text { zing the lobe of the occluder dama- } \\
\text { ged the adventitia of the pulmonary } \\
\text { artery; tamponade occurred on the } \\
2^{\text {nd }} \text { postoperative day }\end{array}$ & $\begin{array}{l}\text { Sternotomy, cardiac de- } \\
\text { compression, LA appendage } \\
\text { control }\end{array}$ & $\begin{array}{l}\text { Patient discharged from } \\
\text { the department on the } 7^{\text {th }} \\
\text { postoperative day. Paying } \\
\text { attention to anatomical } \\
\text { features of the region around } \\
\text { the LA appendage }\end{array}$ \\
\hline 2 & $\begin{array}{l}\text { Bleeding from the femoral } \\
\text { artery }\end{array}$ & $\begin{array}{l}\text { Accidental puncture of the artery } \\
\text { during the procedure, significant } \\
\text { susceptibility to bleeding after } \\
\text { antiplatelet agents }\end{array}$ & $\begin{array}{l}\text { Surgical intervention within } \\
\text { the groin, bleeding site repair, } \\
\text { suturing the wound }\end{array}$ & $\begin{array}{l}\text { Femoral vein puncture under } \\
\text { ultrasound control; in the case } \\
\text { of arterial puncture - Angio- } \\
\text { Seal implantation }\end{array}$ \\
\hline 3 & $\begin{array}{l}\text { Bleeding from the femoral } \\
\text { vein }\end{array}$ & $\begin{array}{l}\text { Accidental puncture of a collateral } \\
\text { branch of the femoral vein. Bleeding } \\
\text { from the femoral vein }\end{array}$ & $\begin{array}{l}\text { Surgical intervention within } \\
\text { the groin, bleeding site repair, } \\
\text { suturing the wound }\end{array}$ & $\begin{array}{l}\text { Femoral vein puncture under } \\
\text { ultrasound control. Compres- } \\
\text { sion dressing }\end{array}$ \\
\hline 4 & $\begin{array}{l}\text { Bleeding from the femoral } \\
\text { vein }\end{array}$ & $\begin{array}{l}\text { Puncture of the lateral wall of the } \\
\text { femoral vein. Bleeding from the } \\
\text { femoral vein }\end{array}$ & $\begin{array}{l}\text { Surgical intervention within } \\
\text { the groin, bleeding site repair, } \\
\text { suturing the wound }\end{array}$ & $\begin{array}{l}\text { Femoral vein puncture under } \\
\text { ultrasound control. Compres- } \\
\text { sion dressing }\end{array}$ \\
\hline
\end{tabular}

\section{Discussion}

As mentioned in the introduction, percutaneous left atrial appendage occlusion is intended for patients with high risk of stroke and contraindications for anticoagulant use [1]. As demonstrated by the PROTECT AF and PREVAIL studies on the basis of randomized studies, the efficacy of occlusion systems has proved to be non-inferior to pharmacotherapy (both with warfarin derivatives and novel oral anticoagulants) in terms of preventing stroke and embolic complications $[2,4,5]$. In the described group of 34 patients, no occurrences of ischemic/hemorrhagic stroke or signs of peripheral embolization were observed during the 6 months of follow-up. In a study by Reddy et al. [3], the incidence of stroke and peripheral embolic complications in a group of 150 patients was $2.3 \%$ per year (hemorrhagic stroke: $1.7 \%$ and bleeding complications: $0.6 \%$ per year). In other large studies, the mean rate of stroke/TIA varied between $2 \%$ and $3 \%$; it was $70 \%$ lower than the value predicted by the $\mathrm{CHA}_{2} \mathrm{DS}_{2}$ VASc score. In a study by López Minguez et al. [6], presenting the 2-year follow-up of a group of 167 PLAAO patients, a statistically significant difference was found between the rate of stroke complications in the PLAAO group and the rate of complications predicted by the $\mathrm{CHA}_{2} \mathrm{DS}_{2}$ VASc scores: $2.4 \%$ vs. $9.6 \%$; $p<0.003$. Similarly, a statistically significant difference was found between the occurrence of bleeding complications in PLAAO patients and the risk predicted by the HAS-BLED scores: $3.1 \%$ vs. $6.6 \% ; p=0.047$ [6].

Thrombi on the occluder are usually located in the upper quadrant between the disk and the left margin of the LA appendage wall. The risk of thrombus development can be reduced by improving the delivery system and implantation technique, using heparin both before and after the transseptal puncture, and measuring the activated clotting time (ACT). The thrombi are usually $5-10 \mathrm{~mm}$ in size and respond well to treatment with low-molecular-weight heparin. When the occluder is covered with epithelium, the risk of thrombus development is low. In the study by López 
Minguez et al., thrombus developed in 8\% of 167 patients. This is consistent with the literature, describing the occurrence of thrombus in $8-17 \%$ of cases [7-14]. In the case of PLAAO procedures, several anticoagulation regimens are recommended after implantation. In the PROTECT AF study [15], within the first 2 months after the implantation of a Watchman occluder, warfarin was administered for 45 days, followed by double antiplatelet therapy. In other studies, double antiplatelet therapy was used for 3 months and followed by ASA alone for the next 3 months [7-14]. In our group, no thrombus development was observed during the 6-month follow-up. For 6 months, all patients adhered to the regimen of double antiplatelet therapy, which was followed by ASA monotherapy.

In order to confirm the efficacy of the employed treatment in all patients, blood platelet activity was determined using the Multiplate analyzer. No ASA resistance was found in our group. Clopidogrel treatment was found ineffective in 5 patients - the results of the platelet activity test (ADP) were within the normal range. The patients stated that they received the standard dose of medication (75 $\mathrm{mg}$ ASA and $75 \mathrm{mg}$ clopidogrel) at the same time each day. According to the literature, ASA resistance occurs in $5 \%$ to as many as $60 \%$ of patients receiving this agent. The reasons are multifactorial, ranging from concurrent use of nonsteroidal anti-inflammatory agents, through increased propensity of platelets to aggregate due to increased catecholamine ejection, to polymorphism of the gene encoding COX-1 [16]. Resistance to standard doses of clopidogrel occurs in 5-10\% of cases. A further $25 \%$ of patients are described as partially sensitive. The causes of resistance are unknown. They are likely associated with a polymorphism within the platelet receptor P2Y12. As stated in the literature, clopidogrel resistance may also result from doses that are too small, especially in the group of patients with high BMI values [16]. The relationship between blood platelet function and body mass was confirmed in a study by Campello et al. [17]. The researchers found a statistically significant relationship between obesity and increased blood platelet activity. Our study revealed a weak correlation between BMI and clopidogrel resistance. The study group was not numerous, as it encompassed only 20 patients. Therefore, further observations will be necessary. No unambiguous management scheme has been established for suspected clopidogrel resistance. Relevant publications recommend increasing the dose or switching to prasugrel. In the case of the 5 patients described in our study, the clopidogrel dose was increased to $150 \mathrm{mg} / \mathrm{day}$, and the patients were advised to report back within 3 months in order to undergo a control Multiplate analysis. A crucial risk factor considered in patients qualified for PLAAO procedures is bleeding resulting from the employed anticoagulation treatment (HAS-BLED scale). The study by López Minguez et al. [6] compared the occurrence of bleeding with the number of hemorrhages predicted by the HAS-BLED scores in a 12-month follow-up of patients after occluder implantation. Significant bleeding occurred in $3.1 \%$ of the patients, while the expected
Tab. IV. Length of hospitalization after PLAAO

\begin{tabular}{lll}
\hline Discharged on the $2^{\text {nd }}$ day after PLAAO & 1 patient & $2.9 \%$ \\
\hline Discharged on the $3^{\text {rd }}$ day after PLAAO & 21 patients & $61.76 \%$ \\
\hline Discharged on the $4^{\text {th }}$ day after PLAAO & 4 patients & $11.76 \%$ \\
\hline Discharged on the $5^{\text {th }}$ day after PLAAO & 2 patients & $5.88 \%$ \\
\hline $\begin{array}{l}\text { Discharged later than on the } 5^{\text {th }} \text { day } \\
\text { after LAAO }\end{array}$ & 6 patients & $17.62 \%$ \\
\end{tabular}

percentage (based on HAS-BLED) was $6.6 \%(p=0.047)$. According to the literature, the risk of bleeding is $3-6 \%$ or even $10 \%$. Most of the described hemorrhages are from the gastrointestinal tract. A decided majority of publications include a follow-up of patients implanted with the Watchman system, which requires the use of warfarin derivatives for 3 months after the implantation. In our group, as mentioned above, the bleeding was only local (puncture of the femoral artery and vein). Bleeding from the gastrointestinal tract was not observed. In the described group, 1 patient suffered from tamponade on the $2^{\text {nd }}$ postoperative day. Its probable cause was the unfavorable anatomy of the appendage and its position in relation to the pulmonary artery. The hooks stabilizing the occluder's lobe damaged the adventitia of the pulmonary artery. In such cases, qualifying the patients for thoracoscopic LAAO using the AtriCLip system should be considered, as proposed by Suwalski et al. [18]. Another system for LA appendage occlusion is the LARIAT system. A study by Bartus et al. is one of the publications presenting examples of its use. Two clinical cases described in their study confirm the effectiveness of occlusion and discuss histological changes - the presence of an inflammatory process, fibrosis, cicatrization, and endothelialization of the endocardial surface of the LA appendage. However, the authors recommend considering prophylaxis in the form of anti-inflammatory agents and antiplatelet therapy (in one of the described cases, thrombi were found within the occluded LA cavity) [19]. As mentioned before, the most common group of complications after implantation were local complications. According to a study by Lewandowski et al., the incidence of local complications after interventional cardiac procedures is estimated at $15-20 \%$. This percentage is higher if systems with diameters larger than $9 \mathrm{Fr}$ are used [20]. The Amplatzer Amulet system is implanted using vascular sheath sizes $12 \mathrm{Fr}$ or $14 \mathrm{Fr}$. Due to vascular complications, we currently perform femoral vein puncture under ultrasound control in every patient qualified for a PLAAO procedure. We are also considering introducing percutaneous occlusion systems. In special cases, it is possible to surgically dissect the femoral vein and suture the punctured vein with a direct suture. At present, we are observing a decreasing number of local postoperative complications among patients qualified for PLAAO prospectively.

The PLAAO procedure is associated with relatively low procedural risk. In accordance with the binding guidelines, the procedure is intended for patients with high risk of 
stroke and contraindications for chronic oral antithrombotic therapy: recommendation class IIb, evidence level B [1]. According to our observations, the number of patients meeting the qualification criteria is rising. We believe that the safest location for the performance of PLAAO procedures is a hybrid cardiac operating room which meets the rigorous aseptic criteria and enables the surgeons to immediately convert to an open procedure if life-threatening complications occur.

\section{Disclosure}

Authors report no conflict of interest.

\section{References}

1. Camm JA, Lip GYH, Raffaele DC, Savelieva I, Atar D, Hohnloser SH, Hindricks G, Kirchhof P. Wytyczne ESC dotyczące postępowania w migotaniu przedsionków na 2012 rok. Kardiol Pol 2012; 70 supl. IV: 197-234.

2. Holmes DR Jr, Lakkireddy DR, Whitlock RP, Waksman R, Mack MJ. Left atrial appendage occlusion opportunities and challenges. JAAC 2014; 63: 291-298.

3. Reddy VY, Doshi SK, Sievert H, Buchbinder M, Neuzil P, Huber K, Halperin JL, Holmes D; PROTECT AF Investigators. Percutaneous left atrial appendage closure for stroke prophylaxis in patients with atrial fibrillation: 2-3 year follow-up of the PROTECT AF (Watchman Left Atrial Appendage System for embolic Protection in Patients with Atrial Fibrillation) trial. Circulation 2013; 127: 720-729.

4. Gangireddy SR, Halperin JL, Fuster V, Reddy VY. Percutaneous left atrial appendage closure for stroke prevention inpatients with atrial fibrillation: an assesment of net clinical benefit. Eur Heart J 2012; 33: 2700-2708.

5. Lip GY, Dagres N, Proclemer A, Svendsen JH, Pison L, Blomstrom-Lundqvist C; Scientific Initiative Committee, European Heart Rhythm Association. Left atrial appendage occlusion for stroke prevention in atrial fibrillation in Europe: results of the European Heart Rhythm Association survey. Europace 2013; 15: 141-143.

6. López Mínguez JR, Asensio JM, Gragera JE, Costa M, González IC, de Carlos FG, Díaz JA, Martín Yuste V, González RM, Domínguez-Franco A, Buendía AB, Garibi JH, Hernández FH, Ribeiro VG. Two-year clinical outcome from the Iberian registry patients after left atrial appendage closure. Heart 2015; 101: 877-883.

7. Park JW, Bethencourt A, Sievert H, Santoro G, Meier B, Walsh K, Lopez-Minguez JR, Meerkin D, Valdés M, Ormerod O, Leithäuser B. Left atrial appendage closure with Amplatzer cardiac plug in atrial fibrillation: initial European experience. Catheter Cardiovasc Interv 2011; 77: 700-706.

8. Reddy VY, Möbius-Winkler S, Miller MA, Neuzil P, Schuler G, Wiebe J, Sick P, Sievert $H$. Left atrial appendage closure with the Watchman device in patients with a contraindication for oral anticoagulation: the ASAP study (ASA
Plavix Feasibillity Study With Watchman Left Atrial Appendage Closure Technology). J Am Coll Cardiol 2013; 61: 2551-2556.

9. López-Mínguez JR, Eldoayen-Gragera J, González-Fernández R, Fernández-Vegas C, Fuentes-Cańamero ME, Millán-Nuńez V, Nogales-Asensio JM, MartínezNaharro A, Sánchez-Giralt S, Doblado-Calatrava M, Merchán-Herrera A. Immediate and one year results in 35 consecutive patients after closure of left atrial appendage with Amplatzer cardiac plug. Rev Esp Cardiol 2013; 66: 90-97.

10. Urena M, Rodés-Cabau J, Freixa X, Saw J, Webb JG, Freeman M, Horlick E, Osten M, Chan A, Marquis JF, Champagne J, Ibrahim R. Percutaneus left atrial appendage closure with the AMPLATZER cardiac plug device in patients with nonvalvular atrial fibrillation and contraindications to anticoagulation therapy. J Am Coll Cardiol 2013; 62: 96-102.

11. Meincke F, Schmidt-Salzmann M, Kreidel F, Kuck KH, Bergmann MW. New technical and anticoagulation aspects for left atrial appendage closure using the Watchman ${ }^{\circledR}$ device in patients not taking warfin. Eurointervention 2013; 9: 463-468.

12. Nietlispach F, Gloekler S, Krause R, Shakir S, Schmid M, Khattab AA, Wenaweser P, Windecker S, Meier B. Amplatzer left atrial appendage occlusion: single center 10-year experience. Catheter Cardiovasc Interv 2013; 82: 283-289.

13. Chun KR, Bordignon S, Urban V, Perrotta L, Dugo D, Fürnkranz A, Nowak B, Schmidt B. Left atrial appendage closure followed by 6 weeks of antithrombotic therapy: a prospective single-center experience. Heart Rhytm 2013; 10: 1792-1799.

14. Plicht B, Konorza TF, Kahlert P, Al-Rashid F, Kaelsch H, Jánosi RA, Buck T, Bachmann HS, Siffert W, Heusch G, Erbel R. Risk factors for thrombus formation on the Amplatzer cardiag plug after left atrial appendage occlusion. JACC Cardiovasc Interv 2013; 6: 606-613.

15. Holmes DR, Reddy VY, Turi ZG, Doshi SK, Sievert H, Buchbinder M, Mullin CM, Sick P; PROTECT AF Investigators. Percutaneous closure of the left atrial appendage versus warfin therapy for prevention of stroke in patients with atrial fibrillation: a randomized non-inferiority trial. Lancet 2009; 374: 534-542.

16. Michos ED, Ardehali R, Blumenthal RS, Lange RA, Ardehali H. Aspirin and clopidogrel resistance. Mayo Clin Proc 2006; 81: 518-526.

17. Campello E, Spiezia L, Zabeo E, Maggiolo S, Vettor R, Simioni P. Hypercoagulability detected whole blood thromboelastometry (ROTEM) and impedance aggregometry (MULTIPLATE) in obese patients. Thrombosis Res 2015; 135: 548-553.

18. Suwalski P, Witkowska A, Drobiński D, Rozbicka J, Sypuła S, Liszka I, Smoczyński R, Staromłyński J, Walecka I, Kosior D. Stand-alone totally thoracoscopic left atrial appendage exclusion using a novel clipping system in patients with high risk of stroke - initial experience and literature review. Kardiochir Torakochir Pol 2015; 12: 298-303.

19. Bartus K, Morelli RL, Szczepanski W, Kapelak B, Sadowski J, Lee RJ. Anatomic analysis of the left atrial appendage after closure with the LARIAT device. Circ Arrhythm Electrophysiol 2014; 7: 764-767.

20. Lewandowski P, Maciejewski P. Powikłania naczyniowe po zabiegach kardiologii interwencyjnej - diagnostyka i postępowanie. Postep Nauk Med 2010; 12: $948-952$. 